\title{
Pandangan Dunia Pengarang dalam Novel Warisan Karya Chairul Harun: Tinjauan Strukturalisme Genetik
}

\author{
Author World-view in Chairul Harun's Warisan: Genetic Structuralism \\ Approach
}

\author{
Tisa Sirefina, Khairil Anwar, Hasanuddin \\ khairrilanwar@gmail.com \\ Universitas Andalas Padang
}

\begin{abstract}
Novel Warisan with a Minangkabau social background that tells the story of a dispute over inheritance. In this case, the novel is analyzed by a genetic structuralism approach that analyzes the structure of the story and relates it to the social structure of the community, then reveals the author's worldview that it reflects.

This study concluded that Warisan's novel by Chairul Harun reflected the worldview of the author as a member of the Minangkabau community who had changed. Changes seen in the patterns of behavior and actions of the people are no longer in line with the Minangkabau philosophy, namely Basandi Syarak Customary, Syarak Basandi Kitabullah. Changes are caused by the influence of colonialization and modernization. The world view is the collective mind, in this case the Minangkabau educated group.
\end{abstract}

Keywords: Warisan, Chairul Harun, author's worldview

\section{PENGANTAR}

Novel sebagai hasil cipta sastra dari satu sisi yang dapat berfungsi sebagai cerminan dari masyarakat pada suatu waktu dan tempat. Dibandingkan dengan genre karya sastra lainnya, seperti drama atau puisi, maka novel merupakan karya sastra yang kompleks berupa karya fiksi naratif. Oleh karena itu, novel merupakan representasi hidup dan kehidupan manusia.

Salah satu novel yang menggambarkan cerminan dari masyarakat adalah novel Warisan karya Chairul Harun yang diterbitkan oleh Pustaka Jaya pada tahun 1979, merupakan salah satu karya terbaik dari Chairul Harun. Novel Warisan juga mendapatkan penghargaan pada tahun 1983 sebagai buku terbaik dari Dewan Kesenian Jakarta. Novel Warisan bercerita mengenai persoalan sosial budaya Minangkabau khususnya masalah sistem pewarisan yang ada dalam masyarakat Minangkabau, yang dirangkum dengan perilaku dan sikap tokohtokoh dalam interaksi kesehariannya sudah melenceng dari ajaran adat dan agama Islam yang dikenal dengan falsafah Minangkabau, yaitu Adat Basandi Syarak,Syarak Basandi Kitabullah.

Falsafah Adat Basandi Syarak, Syarak Basandi Kitabullah adalah pedoman dasar orang Minangkabau yang begitu dijunjung tinggi oleh masyarakatnya. Namun, wujud nyata dari itu yang tidak tampak dalam novel Warisan. Chairul Harun ingin memberikan gambaran bahwa masyarakat Minangkabau telah berubah akibat 
pembaharuan dari persentuhan dengan kebudayaan lain. Hingga terjadi penyimpangan-penyimbangan dari nilai adat dan agama Islam yang menjadi sumber dasar masyarakat Minangkabau selama ini. Perubahan tersebut tergambar melalui tingkah laku dan tindakan-tindakan yang dilakukan oleh tokoh-tokoh yang ada dalam novel Warisan. Novel Warisan karya Chairul Harun bercerita mengenai konflik perebutan harta warisan Bagindo Tahar akibat punahnya jurai (keluarga menurut sistem matrilineal yang dimulai dari seorang perempuan, anak-anak sampai pada cicitnya) dari keluarga Bagindo Tahar yang hanya memiliki seorang adik perempuan bernama Siti Baniar. Sedangkan Siti Baniar hanya memiliki seorang putra bernama Sidi Baharuddin, keduanya sudah terbaring tak berdaya di tempat tidur selama 10 tahun akibat penyakit biring (sejenis penyakit kulit).

Gejolak perebutan harta warisan yang terjadi dalam kaum Bagindo Tahar semakin memanas dengan kedatangan Rafilus ke Kurai Taji. Kedatangan Rafilus ke Kurai Taji, dianggap bukan sebagai ungkapan rasa peduli Rafilus terhadap keluarga bako-nya yang sedang sakit, lebih dari itu Siti Baniar dan Sidi Baharudin menganggap kedatangan Rafilus adalah untuk menjemput harta warisan yang akan diserahkan oleh Bagindo Tahar kepada anaknya tersebut. Hingga pihak-pihak yang sejak dulu mengincar harta warisan tersebut merasa terancam dan mereka mulai berpikir untuk mencari jalan lain agar tetap bisa mendapat bagian dari harta tersebut, sampai menimbulkan rasa saling curiga dan sikap kewaspadaan antara mereka yang begitu menginginkan harta warisan tersebut. Dalam keadaan seperti ini teman bisa menjadi lawan dan lawan bisa menjadi teman.

Novel Warisan juga memperlihatkan hubungan antara laki-laki dan perempuan yang tak lazim yang berkembang dalam masyarakat Minangkabau. Sebuah hubungan yang hanya berlandaskan hawa nafsu dan hasrat duniawi semata tanpa mengindahkan norma dan agama Islam yang mengikat mereka sebagai orang Minangkabau. Hubungan itu terlihat pada Rafilus dalam memperlakukan Maimunah, Farida dan Upiak Dedok sebagai pelampiasan hasrat birahinya semata tanpa memandang sah atau tidaknya hubungan antara mereka, yang didukung oleh sikap terbuka yang diperlihatkan Maimunah, Farida dan Upiak Dedok yang menerima perlakuan Rafilus begitu saja. Kemudian hubungan yang terjalin antara Asnah dengan Tan Rudin di belakang Sidi Baharuddin sebagai suami sah dari Asnah, serta Tuanku Salim memilih menikah kembali dengan janda bernama Upiak Denok tanpa sepengetahuan dari Siti Baniar sebagai istri sahnya. Djamari (Djamari, 2010) juga menyatakan, Warisan karya Chairul Harun selain mengandung konflik sosial juga konflik antartokoh melalui gambaran pernikahan dalam sistem matrilineal di Minangkabau. Senada dengan pernyataan itu, menurut Darussalam (Darussalam, 2017) novel Warisan ini menggambarkan fenomena sosial yang universal yaitu hubungan perselingkuhan, perceraian, sistem pewarisan, dan hubungan kekerabatan.

Selain menggambarkan hubungan antara laki-laki dan perempuan yang tidak dilandasi ikatan yang sah, novel Warisan juga memperlihatkan kurang harmonisnya hubungan antara Rafilus dengan Siti Baniar yang dalam adat Minangkabau disebut hubungan antara anak pisang (anak dari saudara laki-laki ibu) dan induk bako (saudara perempuan dari ayah). Hubungan yang terlihat antara keduanya hanyalah rasa saling curiga yang diakibatkan rasa waspada Siti Baniar yang menganggap kedatangan Rafilus adalah untuk mengambil harta keluarganya. Bagi Rafilus senyuman dari Siti Baniar hanyalah basa-basi belaka yang di dalamnya mengandung arti lain.

Adanya pengaruh dari bentuk pemerintahan yang ditinggalkan oleh Belanda, mengingat novel Warisan adalah salah satu dari karya-karya sastra dari sastrawan Indonesia yang bertemakan keminangkabauan yang lahir setelah penjajahan kolonial Belanda. Selain itu persentuhannya budaya Minangkabau dengan budaya lain (modernisasi), secara perlahan turut berpengaruh terhadap perubahan pola pikir masyarakat Minangkabau yang 
ditunjukkan melalui tingkah laku dan tindakan orang Minangkabau, seperti yang kutipan Chairul Harun dalam novel Warisan ini bahwa "semua tampak demikian ketat, demikian fantastis dengan nilai-nilai adat serta kesusilaan, tetapi jauh di bawahnya mengalir dengan deras arus kebebasan untuk menikmati kehidupan duniawi semata".

Persoalan yang diangkat dalam novel Warisan ini menggambarkan fakta kemanusiaan dan realitas sosial masyarakat yang hadir dalam sebuah karya sastra dan untuk mengungkapkan makna dari fakta kemanusian yang ada dalam karya sastra. Sebuah karya sastra tidak akan utuh apabila hanya dilihat dari struktur yang ada di dalam karya itu sendiri. Ada struktur luar yang turut melatarbelakangi penciptaan sebuah karya sastra, yaitu struktur sosial masyarakat. Sehingga tergambarlah bagaimana pandangan dunia yang coba digambarkan oleh Chairul Harun yang mewakili kerangka berpikir masyarakat Minangkabau melalui fakta-fakta kemanusian yang ada dalam novel Warisan (Rikardo, 2014; Saputri, Thahar, \& Hayati, 2016).

\section{KERANGKA TEORI DAN METODOLOGI}

Goldmann menjelaskan strukturalisme genetik sebagai hubungan antara sastra dengan masyarakat yang melahirkan karya sastra tersebut melalui pandangan dunia atau ideologi yang diekspresikannya (Faruk, 1988:43). Goldmann menegaskan bahwa strukturalisme genetik merupakan sebuah pendekatan yang totalitas, yaitu penelitian terhadap karya sastra tidak bisa dipisahkan antara satu aspek dengan aspek lainnya yang saling berkaitan, karena sebuah karya sastra harus dilihat sebagai satu kesatuan yang bulat dan utuh. Menganalisis sebuah karya sastra dengan menggunakan pendekatan strukturalisme genetik, harus memperhatikan aspek struktur teks sastra, latar belakang penciptaan dan latar belakang sosial budaya serta sejarah masyarakatnya. Jadi, pendekatan strukturalisme genetik, selain menghubungkan struktur dalam dan struktur luarnya juga menghubungkannya dengan aspek sejarah yang melatarbelakangi lahirnya sebuah karya sastra.

Goldmann membangun seperangkat kategori yang saling bertautan satu dengan yang lainnya sehingga membentuk sesuatu yang disebut dengan strukturalisme genetik tersebut. Fakta kemanusian adalah segala hasil aktivitas atau perilaku manusia baik yang verbal maupun yang fisik dan berusaha dipahami oleh ilmu pengetahuan. Fakta tersebut berwujud aktivitas sosial tertentu, aktivitas politik tertentu, maupun kreasi kultural seperti filsafat, seni rupa, seni musik, seni patung dan seni sastra (Faruk, 2003).

Goldmann berpendapat bahwa semua fakta kemanusian merupakan sesuatu struktur yang bermakna, bahwa fakta itu mempunyai sesuatu yang dipertimbangkan struktur tertentu. Oleh karena itu, pemahaman mengenai fakta-fakta kemanusian harus mempertimbangkan struktur dan artinya. Fakta kemanusiaan dikatakan mempunyai arti karena hasil usaha manusia mempunyai keseimbangan yang lebih baik dalam hubungannya dengan dunia sekitarnya. Fakta kemanusiaan bukanlah sesuatu yang muncul begitu saja, melainkan hasil kreativitas manusia sebagai subjeknya. Dalam hal ini subjek penelitian fakta kemanusian dibedakan menjadi dua, yaitu subjektif individual dan subjektif kolektif. Subjek individual merupakan subjek fakta individu dan subjek kolektif merupakan subjek fakta sosial. Menurut Goldmann kelompok sosial yang bisa dianggap sebagai subjektif dari satu pandangan dunia hanya kelompok sosial yang memiliki gagasan dan aktivitas cenderung ke arah penciptaan suatu pandangan dunia (Faruk, 2003). 
Menurut Goldmann (Faruk, 2003)pandangan dunia merupakan istilah yang cocok dari kompleks menyeluruh dari gagasan-gagasan, aspirasi-aspirasi dan perasaan-perasaan yang menghubungkan secara bersamasama anggota suatu kelompok sosial tertentu dan mempertentangkan dengan kelompok-kelompok sosial lainnya sebagai suatu pemahaman kesadaran subjek kolektif. Sebagai suatu kesadaran kolektif, pandangan dunia berkembang sebagai hasil dari situasi sosial tertentu yang dihadapi oleh subjek kolektif yang dimilikinya. Ini merupakan produk interaksi antara subjek kolektif dengan situasi sekitarnya, pandangan dunia tidak lahir dengan tiba-tiba, transformasi mentalitas yang lama secara perlahan-lahan dengan bertahap diperlukan demi terbangunnya sebuah mentalitas yang baru.

Pandangan dunia menghubungkan antara karya sastra dengan kehidupan masyarakatnya. Hal ini sebabkan oleh kenyataan bahwa pandangan dunia dipandang sebagai hasil dari hubungan antara kelompok sosial yang memilikinya dengan situasi sosial dan ekonomi pada saat tertentu. Goldmann menjelaskan untuk mengetahui dan memahami pandangan dunia pengarang, harus dilihat dari struktur cerita sebuah karya sastra. Dari struktur ceritanya kemudian dicari jaringan-jaringan yang membentuk kesatuannya. Untuk mencapai pemahaman terhadap pandangan dunia pengarang, struktur cerita harus dipahami melalui pembacaan terhadap teks, di mana teks tersebut melatarbelakangi penciptaan suatu karya sastra (Fananie, 2000).

Berhubungan penelitian ini menganalisis sebuah karya sastra berupa novel dengan pendekatan strukturalisme genetik, maka metode yang digunakan adalah metode dialetika sebagai pembongkaran teks yang terdapat di dalam novel Warisan, baik teks tersurat maupun teks yang tersirat. Menurut Goldmann sudut pandang dialektika mengatakan bahwa setiap pikiran tidak pernah bergerak seperti garis lurus. Setiap fakta atau gagasan individual hanya akan mempunyai arti bila ditempatkan di dalam keseluruhan (Faruk, 1988). Prinsip dasar metode dialetika adalah pengetahuan mengenai fakta-fakta kemanusiaan yang akan tetap abstrak apabila tidak dibuat konkrit dengan mengintegrasikannya kedalam keseluruhannya. Sehubungan dengan itu, metode dialetika mengembangkan konsep, yaitu "pemahaman-penjelasan".

Pemahaman adalah usaha mendeskripsikan struktur objek yang dipelajari, sedangkan penjelasan adalah usaha menggabungkan ke dalam struktur yang lebih besar, yakni struktur sosial. Pelaksanaan konsep "pemahaman-penjelasan" hampir sama dengan konsep cara kerja dalam penelitian "Hermeneutik", yaitu memahami keseluruhan berdasarkan unsur-unsurnya dan memahami unsur-unsur berdasarkan keseluruhannya. Jadi yang dimaksud dengan pemahaman penjelasan adalah usaha untuk memahami dan memaknai struktur objek sebuah karya sastra (Faruk, 2003).

Data yang diperoleh terdiri dari data primer dan data sekunder yang terdapat dalam novel Warisan karya Chairul Harun. Kemudian data sekundernya berupa bahan-bahan yang diperoleh dari pustaka yang relevan dan mendukung penelitian ini seperti hal-hal yang berkaitan dengan novel ini sendiri maupun tentang pengarang dan juga tentang sosial budaya Minangkabau.

Data yang terkumpul kemudian dianalisis menggunakan pendekatan strukturalisme genetik dengan metode dialetika. Dengan membongkar dan mengaitkan tiap unsur-unsur yang membangunnya, seperti tema, tokoh dan penokohan, alur, latar, serta ada unsur sosialnya, seperti adat-istiadat, agama, budaya masyarakatnya. Dengan mengaitkan semua unsur karya sastra yang terdapat dalam novel Warisan karya Chairul Harun yang dapat menggambarkan pandangan dunia seorang Chairul Harun yang mewakili kerangka berpikir masyarakat Minangkabau yang diwakili oleh masyarakat Kuraitaji, Pariaman. Salah satu tujuan dari analisis strukturalisme 
genetik adalah bahwa kerangka imajinatif tidak akan bisa dipahami di luar kerangka Empiris. Meskipun karya sastra merupakan karya fiksi, namun ada fakta dan kenyataan dalam karya sastra. Kenyataan dalam karya sastra bersifat interpretatif subjektif yang tergambar dari unsur yang membangun karya sastra tersebut.

\section{HASIL DAN PEMBAHASAN}

Ada tiga konsep yang digunakan dalam menganalisis novel Warisan karya Chairul Harun yaitu, struktur cerita, struktur penceritaan dan struktur kemaknaan. Struktur cerita menjelaskan tentang keterkaitan antara unsur yang terdapat pada bab-bab dalam novel Warisan. Struktur penceritaan menjelaskan bagaimana keterkaitan antara unsur yang membangun karya sastra seperti, latar, alur, tokoh dan penokohan dalam novel Warisan. Sementara struktur kemaknaan melihat hubungan antara struktur cerita dengan struktur penceritaan yang membentuk sebuah makna sebagai tema sentral dalam karya sastra. Artikel ini menguraikan struktur penceritaan dan struktur kemaknaan novel Warisan.

\section{STRUKTUR PENCERITAAN}

Dalam novel Warisan karya Chairul Harun terdapat beberapa unsur yang harus dicermati untuk suatu keterpaduan yang tidak bisa berdiri sendiri karena satu unsur saja tidak akan berarti tampa adanya unsur-unsur yang lainnya. Oleh karena itu, harus ada unsur yang membangun karya sastra, seperti alur, latar, tokoh dan penokohan. Struktur penceritaan merupakan jalinan hubungan alam penciptaan pengarang dengan alat sastra tertentu seperti latar, sintaksis dan gaya kepengarangan yang merupakan hubungan struktur cerita yang dipergunakan pengarang dalam ciptaannya. Struktur penceritaan tersebut berfungsi untuk meyakinkan pembaca bahwa apa yang terjadi di dalam sebuah karya sastra merupakan peristiwa yang benar-benar terjadi (Junus, 1986).

\section{Aspek Latar}

Latar adalah segala keterangan, petunjuk, pengacuan yang berkaitan dengan waktu dan suasana terjadinya peristiwa secara keseluruhan yang terdapat dalam novel (Sudjiman, 1991). Menurut Kenney latar tersebut meliputi penggambaran lokasi geografis, termaksud topografi, pemandangan, sampai pada perincian perlengkapan sebuah ruangan, pekerjaan atau kisibukan sehari-hari tokoh, waktu berlakunya kejadian, masa sejarahnya dan emosional para tokoh. Latar dikategorikan menjadi empat bagian diantaranya (Sudjiman, 1991).

Latar tempat menunjuk pada lokasi terjadinya peristiwa yang diceritakan dalam sebuah karya fiksi (Nurgiyantoro, 2002). Dalam novel Warisan karya Chairul Harun terdapat empat lokasi tempat yang digambarkan pengarang dalam novel Warisan, seperti kampung Kurai Taji, Pariaman, Padang Panjang dan Jakarta.

"Loko tua buatan Jerman pada penghujung abad ke 19 akhirnya kehabisan tenaga dan berhenti lima puluh meter menjelang stasiun Kurai Taji. Kereta api itu terlambat lebih dari tiga jam. Hal itu sudah lazim. Memang pada masa ini tidak ada lagi yang tepat. Aturan dan jadwal hanya tertulis di atas kertas atau papan tulis" (Harun, 1979).

Dari penggambaran Kurai Taji terlihat bahwa pengarang ingin melukiskan bahwa pada masa itu aturanaturan yang ada dalam masyarakat Minangkabau sudah mengalami perubahan. Penggambaran tentang kota Jakarta dilukiskan pengarang bahwa tujuan awal kedatangan Rafilus ke Kurai Taji adalah untuk memenuhi amanat ibu agar membawa ayah mereka ke Jakarta. Semuanya ingin agar Bagindo Tahar mau melakukan pengobatan di Jakarta yang peralatan medisnya lebih baik dari pada rumah sakit atau pengobatan tradisional yang ada di Kurai 
Taji. Selain itu alasan Rafilus ingin membawa Bagindo Tahar ke Jakarta adalah kalau di Jakarta, Bagindo Tahar ada yang mengurus sedangkan kalau di Kuraitaji tidak ada yang akan mengurus karena adik dan kemenakannya juga menderita penyakit, jangankan mengurus orang lain mengurus dirinya sendiri tidak lagi mampu. Mereka memerlukan orang lain untuk membantu mereka beraktivitas dan itu hanya di sekitar tempat tidur.

“ Laki-laki yang terpandang di daerah Pariaman biasanya dipinang dengan uang jemputan. Besarnya uang jemputan tergantung pada martabat laki-laki itu. Hal ini tergambar dari gelar ayahnya, terutama yang begelar Sidi dan Bagindo. Martabat kaum ibu dan mamak laki-laki itu juga ikut menentukan. Uang jembutan itu ada yang hilang, artinya uang itu sepenuhnya digunakan oleh laki-laki yang dipinang untuk keperluan pribadinya. Tetapi lebih banyak uang jemputan itu digunakan oleh laki-laki untuk keperluan hidup suami istri pada awal perkawinan, misalnya untuk membeli ranjang, perabotan rumah tangga, periasan emas dan perabotan lainnya yang meninggikan martabat dalam masyarakat" (Harun, 1979 : 78).

Pariaman adalah salah satu daerah rantau Minangkabau yang memiliki tradisi berbeda dari daerah lainnya dalam hal pinangan yang merupakan salah satu rangkaian dari sebuah perkawinan yang ada di Minangkabau. tradisi pinangan tersebut dikenal dengan istilah uang japuik (uang jemputan). Bagi masyarakat Pariaman uang jemputan sudah menjadi tradisi yang mereka warisi secara turun temurun dan telah mendarah daging dengan tradisi yang dimiliki oleh masyarakatnya. Hingga sulit untuk dihilangkan karena itu bagian dari diri mereka selama ini. Uang jemputan menjadi syarat mutlak bagi kedua keluarga sebelum menentukan hari pernikahan. Jadi atau tidaknya sebuah pernikahan di Pariaman tergantung pada persetujuan uang jemputan antara kedua keluarga yang akan melangsungkan pernikahan tersebut. Besar uang jemputan tergantung pada gelar kebangsawanan dan gelar pendidikan yang dimiliki oleh laki-laki di Pariaman, semakin tinggi gelar kebangsawanan dan pendidikan serta latar belakang keluarga dari laki-laki di Pariaman maka akan semakin tinggi pula uang jemputannya. Pada saat ini pendidikanlah yang paling berpengaruh dalam menentukan besarnya uang jemputan bagi laki-laki di Pariaman.

Penggambaran Kota Padang Panjang dilukiskan oleh pengarang ketika Rafilus datang ke Kota Padang Panjang untuk menemui keluarga dari ibunya. Ia harus berbicara dengan mamaknya, yaitu Datuak Batuah mengenai pinangan yang datang dari keluarga Arneti. Membicarakan mengenai uang jemputan yang ia terima atas pinangan keluarga Arneti, apakah akan diterima atau ditolak.

“ Gelanggang pacuan kuda Bancah Laweh sangat ramai pada hari kedua masa pacu kuda di Padang Panjang. Lebih dari seratus ekor kuda segala kelas, baik kuda tua maupun muda ikut ambil bagian. Hari itu hari senin, hari pasar di Padang Panjang. Gelanggangan penuh oleh penonton yang datang dari segenap pelosok. Secara tidak resmi, hari senin pada saat pacu kuda, sekolah diliburkan. Para pelajar dan mahasiswa diizinkan melihat pacuan kuda. Daftar absen tidak diisi. Tribun penuh sesak oleh orang-orang terkemuka bersama anak istri. Melihat pacu kuda dari tribun tertutup ini tidak menarik. Kesempatan untuk melihat kuda berlari sedikit, karena orang lebih senang menonton di sekeliling gelanggang di tempat terbuka, atau di kaki Bukit Tui yang ketinggian" (Harun, 1979:86).

"Arneti sedang menghabiskan masa liburnya di kampung. Ia sedang mempersiapkan dirinya hendak mencapai gelar sarjana muda pada FKSS IKIP Padang Jurusan Bahasa Indonesia " (Harun, 1979:24).

“Arneti sejak kematian Bagindo Tahar lebih banyak berada di Padang. Di Padang ia sekali-kali datang ke kampus, tetapi lebih banyak bepergian bersama laki-laki lainnya (Harun, 1979:130).

Penggambaran Kota Padang yang dilukiskan oleh pengarang sebagai kota tempat Arneti akan mencapai gelar sarjananya pada Universitas FKSS IKIP Padang. Di kota inilah Arneti kehilangan keperawanannya akibat 
pergaulan yang terlalu bebas tampa memikirkan dampak yang akan ditimbulkan dari apa yang dia perbuat. Hingga pacarnya pergi tanpa ada kabar sebelum Arneti meminta pertanggung jawaban atas perbuatan yang mereka lakukan. Alasan inilah juga kenapa Arneti ingin minta tolong agar Rafilus mau menikahinya agar ibu dan masyarakat Kuraitaji tidak tahu apa yang ia lakukan selama kuliah di Padang.

Latar waktu berhubungan dengan masalah kapan terjadinya suatu peristiwa yang diceritakan di dalam sebuah karya sastra, yang biasanya berkaitan dengan waktu faktual dan waktu yang berkaitan dengan peristiwa sejarah.

Datangnya pinangan dari keluarga Arneti untuk meminang Rafilus yang rencananya akan dilaksanakan setelah 40 hari kematian dari Sidi Baharudin. Namun, 40 hari yang dijanjikan untuk pernikahan Arneti dan Rafilus menjadi hari meninggalnya Siti Baniar menyusul anaknya. Ia meninggal tepat sehari sebelum pernikahan anak Bakonya. Ini menjadi duka yang paling mendalam bagi Bagindo Tahar, harus kehilangan adik dan kemenakannya dalam waktu yang singkat dan berturut-turut. Hal itu terlihat pada kutipan di bawah ini.

“ Bagindo Tahar dan Siti Baniar, menyetujui niat baik Rakena itu serta menyarankan perkawinan dilangsungkan setelah upacara 40 hari kematian Sidi Baharudin” (Harun, 1979:79).

Perkawinan antara Rafilus tetap dilaksanakan walaupun harus diundur 10 hari setelah kematian Siti Baniar. Hal ini terlihat pada kutipan di bawah ini.

“Waktu itu telah sore, 10 hari sesudah kematian Siti Baniar. Pada wajah Arneti tergambar perasaan bangga. Tetapi Rafilus tenang, entah gembira entah gusar. Sebenarnya ia menolak acara ini, tetapi semuanya yang mengatakan bahwa ia harus melakukannya" (Harun, 1979:112).

Pembagian harta warisan Bagindo Tahar dilaksanakan pada hari keempat puluh kematiannya, sesuai amanatnya bahwa Rafiluslah yang akan bertanggung jawab untuk membagikan harta warisan yang selama ini menjadi sengketa bagi kaumnya. Harta warisan tersebut harus dibagikan secara adil pada anak-anaknya serta orang-orang yang memang pantas untuk mendapatkannya. Hal ini tergambar dari kutipan di bawah ini.

“ Terima kasih atas kehadiran Bapak-bapak, Ibu-ibu serta kakak-kakak dan adik-adikku yang seayah. Aku menganggap pertemuan keluarga seperti ini perlu diadakan karena aku akan kembali ke Jakarta. Ayahku telah meninggal empat puluh hari yang lalu. Tidak ada adik seibu atau kemenakan yang ditinggalkan. Menurut adat jurai ayahku telah punah. di dalam tabung ini tersimpan surat-surat tentang harta ayahku. Soal inilah yang harus diselesaikan hari ini " (Harun, 1979:135).

Empat puluh hari setelah kematian Bagindo Tahar, Rafilus juga akan kembali ke Jakarta. Semua urusan yang menahannya di Kuraitaji telah ia selesaikan sesuai amanat ayahnya. Alasan utamanya bertahan di Kuraitaji adalah keberadaan ayahnya, tapi ayahnya lebih memilih kuraitaji sebagai tempat ia beristirahat untuk selamanya dari pada ikut dengannya ke Jakarta.

“ Kepada ibu dan adik-adiknya Rafilus sesudah megabarkan kematian ayahnya dan berjanji kembali ke Jakarta setelah selamatan 40 hari. Dari Rifki ia mendapatkan kiriman uang untuk keperluan mendoa dan menembok kuburan. Mereka tidak bisa meninggalkan Jakarta" (Harun, 1979:129). 
Setelah meninggalkan Kuraitaji tidak cukup 3 bulan Rafilus beserta ibu dan adik-adiknya kembali datang ke Kuraitaji untuk mengunjungi pusara Bagindo Tahar. Bagi Rafius kedatangannya kembali ke Kuraitaji adalah untuk menjemput dan mengambil warisan ayahnya yang tidak akan digugat oleh siapapun, ia adalah kemenakan jauh dari Bagindo Tahar, yaitu Maimunah yang ternyata telah mengandung anak dari Rafilus. Hal ini tergambar dari kutipan di bawah ini.

“ Tidak cukup tiga bulan kemudia Rafilus datang kembali ke Kuraitaji. Ia datang bersama ibunya dan adiknya Ita. Resminya kedatangan mereka mengunjungi pusara Bagindo Tahar kerena hari akan puasa. Tetapi sebenarnya Rafilus ingin mempertemukan ibu dan adiknya dengan Maimunah" (Harun, 1979:149).

Dari uraian di atas, terlihat bahwa pengarang menggambarkan latar waktu yang singkat dan tidak terlalu rinci, karena pengarang lebih memfokuskan pada tahapan peristiwa dan perkembangan konflik yang terjadi dalam novel Warisan.

Latar sosial berkaitan dengan hal-hal yang berhubungan dengan perilaku dari kehidupan sosial masyarakat di suatu tempat yang diceritakan di dalam karya sastra. Tata kehidupan sosial masyarakat yang mencakup berbagai masalah dalam lingkungan yang cukup kompleks berupa kebiasaan hidup, adat istiadat, tradisi, keyakinan, pandangan hidup, cara berpikir dan bersikap (Nurgiyantoro, 2002). Latar sosial juga dapat berhubungan dengan status sosial tokoh yang bersangkutan di dalam lingkungan masyarakat, misalnya status sosial yang diukur dengan tinggi, menengah dan rendah. Latar sosial yang terdapat dalam novel Warisan karya Chairul Harun, menggambarkan keadaan masyarakat Minangkabau yang telah mengalami perubahan. Perubahan itu dalam bentuk perilaku dan sikap masyarakat Minangkabau. Banyak hal-hal yang dasar dari kehidupan masyarakat Minangkabau yang telah berubah dan tidak sejalan lagi dengan falsafah masyarakat Minangkabau yang dijunjung tinggi oleh masyarakatnya selama ini.

Masyarakat Minangkabau dikenal sangat memegang teguh adat Alam Takambang Jadi Guru yang menjadi pedoman mereka hingga masuknya agama Islam ke Minangkabau, apa yang telah mereka atur di dalam adat ternyata sejalan dengan ajaran Islam hingga lahirlah falsafah Adat Basandi Syarak, Syarak basandi Kitabullah yang dijadikan sebagai pedoman dan aturan tertinggi dalam kehidupan masyarakat Minangkabau hingga sampai pada saat ini. Namun hal-hal dasar itulah yang telah berubah, jauh di dalamnya sikap dan tingkah laku masyarakatnya masih belum sepenuhnya selaras dan sejalan aturan adat dan agama Islam. Wujud nyata dari Adat basandi syarak, syarak basandi kitabullah masih jauh kalau melihat bagaimana perilaku masyarakatnya yang digambarkan oleh Chairul Harun dalam novel Warisan ini. Tokoh-tokohnya yang masih terlena akan arus kebebasan dan kenikmatan duniawi yang hanya bersifat sementara.

Salah satu perubahan dasar dalam masyarakat Minangkabau yang digambarkan dalam novel Warisan, yaitu bagaimana tokoh-tokohnya memandang arti sebuah pernikahan, betapa rapuhnya fondasi pernikahan yang ada dalam masyarakat Minangkabau. Arti pernikahan hanyalah sebuah alat untuk mencapai tujuan masingmasingnya. Pernikahan hanya mengikat mereka akan status tidak pada sikap dan tindakan mereka dalam menjalankan kehidupan sebuah pernikahan. Ini terlihat pada pernikahan Rafilus dengan Arneti, Sidi Baharudin dengan Asnah dan Tuanku Salim dengan Siti Baniar.

Pernikahan bagi Rafilus dan Arneti hanyalah sebagai toleransi untuk mewujudkan kepentingan keduanya, khususnya bagi Arneti. Arneti meminta untuk dinikahi oleh Rafilus hanya untuk menutupi aib yang 
telah dia buat. Arneti sudah tidak perawan lagi ketika ia melakukan dengan pacarnya saat masih kuliah di Padang. Seorang wanita di Kuraitaji akan lebih terpandang menjadi janda dari pada seorang wanita yang tidak perawan lagi karena tidak akan ada yang mau meminangnya. inilah yang ditakuti oleh Arneti hingga ia meminta bantuan pada Rafilus. Menurutnya Rafilus besar di Jakarta dan ia paham bagaimana pergaulan dan kebebasan hidup di kota besar.

Pernikahan hanya sebagai status dan tidak berpengaruh bagi Rafilus terlihat pada sikap dan tindakan Rafilus terhadap Maimunah. Sejak awal kedatangan Rafilus ke Kurai Taji. Maimunah memang sudah menaruh perhatian terhadap Rafilus, begitu pun sebaliknya. Jadi Maimunah tidak akan menolak perlakuan Rafilus terhadapnya dan ia memang sudah berjanji akan mengabdikan diri pada Rafilus.

“Maimunah membayar kekalahan taruhan, pacu kuda di Padang Panjang. Rafilus menciumnya ketika Murni dan Utih Darama sudah tidur lelap. Maimunah menerima ciuman ini dengan seluruh kehangatan dan gairah yang meledak dari kesepian yang dialaminya sebagai seorang janda" (Harun, 1979:95).

Dari kutipan di atas, mengambarkankan bahwa Rafilus tidak terpengaruh akan pernikahannya dengan Arneti, meskipun sudah dipinang oleh keluarga Arneti namun ia masih bebas melakukan apa pun yang dia inginkan. Tindakan seperti itu juga terlihat ketika ia lari dengan Farida pada malam pertama pernikahannya dengan Arneti, malam setelah ia melaksanakan pesta pernikahannya dengan Arneti.

“ Kalau orang lain mengetahui Ajo lari malam dengan aku, orang akan menyalahkan aku, atau orang bisa mengatakan aku orang hebat, seorang janda berhasil melarikan suami orang pada malam pertama."

"Malam pengantin untuk Arneti aku berikan pada mu. "

Rafilus menyerat Farida ke atas pondok tempat Arneti memohon pertolongannya dan mengungkapkan rahasia dirinya (Harun, 1979:114).

Setelah menikahi Arneti, Rafilus lebih memilih tinggal di rumah bako-nya dari pada tinggal di rumah keluarga Arneti. Arneti yang juga mengetahui bahwa Rafilus tidak melaksanakan kewajiban dan tanggung jawab sebagai seorang suami, lebih memilih kembali ke Padang dan menganggap pernikahannya dengan Rafilus tidak memiliki arti apa pun baginya, selain rasa terima kasih telah menyelamatkan harga dirinya dimata masyarakat Kurai Taji. Bahkan Arneti sudah memiliki laki-laki lain selama ia di Padang, padahal statusnya masih sebagai istri dari Rafilus.

Pernikahan antara Asnah dan Sidi Baharudin juga tidak mencerminkan arti dari pernikahan yang sesungguhnya. Pernikahan keduanya memiliki tujuan masing-masing untuk memenuhi kepentingan mereka sendiri. Asnah yang dengan mudahnya tanpa rasa bersalah menjalin hubungan dengan laki-laki lain di belakang suaminya.

Makna pernikahan juga tidak terlihat pada pasangan Tuanku Salim terhadap Siti Baniar. Tuanku Salim menikahi Siti Baniar hanya karena harta yang dimiliki oleh Siti Baniar, ditambah lagi fakta bahwa Siti Baniar dalam keadaan sakit. Membuat Tuanku Salim semakin bebas menggunakan harta Siti Baniar sesuka hatinya bahkan menikah lagi dengan seorang janda yang bernama Upiak Denok tanpa sepengetahuan Siti Baniar dan Bagindo Tahar. Pernikahan Tuanku Salim dan Upiak Dedok terjadi pada malam Siti Baniar meninggal, hingga ia tidak ada di rumah saat Siti Baniar meregang nyawa. Perilaku dari Tuanku Salim tergambar pada kutipan di bawah ini. 
“Aku mencurigai Tuanku Salim sejak aku masih kecil, ketika aku masih di rumah ini, sebagai seorang laki-laki dan suami apa usahanya ? Di satu sagi tampaknya ia mengabdi dan bersedia menjadi budak Etek Baniar, tetapi pada segi lain ia menggerogoti kekayaan bakoku, aku dengar ia akan kawin dengan Upiak Dedok" (Harun, 1979:75).

Perubahan masyarakat Minangkabau tidak hanya terlihat dari arti dan makna sebuah pernikahan, tetapi juga pada sikap dan peran mamak dalam adat Minangkabau. Peran seorang mamak di Minangkabau dapat digambarkan dalam pepatah adat Minangkabau yang mengatakan anak dipangku kemenakan dibimbing, ia berkewajiban untuk mendidik, membimbing dan mengayomi kemenakannya. Namun peranan mamak tidak tampak pada apa yang dilakukan oleh Ajo Pekok terhadap Farida. Ia seakan "menjual” dan menyerahkan Farida pada Rafilus hanya untuk kepentingannya, yaitu harta warisan Bagindo Tahar. Tidak ada sikap melindungi dan menjaga martabat dari kemenakan perempuannya.

Melalui latar sosial yang digambarkan oleh Chairul Harun dalam novel Warisan ini, terlihat bahwa masyarakat Minangkabau sudah tidak memikirkan bagaimana tingkah laku dan sikap mereka yang tidak sesuai dengan aturan adat dan agama Islam lagi. Pola kehidupan yang bebas asalkan bisa menikmati kehidupan duniawi yang tanpa mereka sadari hanya bersifat sementara, meskipun itu melanggar adat istiadat mereka sendiri dan agama Islam yang mengikat mereka.

\section{Aspek Alur}

Alur merupakan unsur yang sangat penting dalam membangun sebuah karya sastra. Alur adalah struktur gerakan yang terdapat dalam karya fiksi atau drama. Menurut Stanton alur adalah cerita yang berisi urutan kejadian namun tiap kejadian itu hanya dihubungkan secara sebab akibat, peristiwa yang satu disebabkan atau menyebabkan peristiwa yang lain. Cerita yang dibagun dari awal sampai akhir tidak akan terlepas dari gerak laku tokoh-tokoh dalam cerita yang akan membentuk sebuah alur dalam cerita sebuah novel. Peristiwa yang dialami tokoh dalam cerita akan memberikan gamabaran yang jelas tentang alur yang terdapat dalam cerita (Nurgiyantoro, 2002).

Dalam novel Warisan karya Chairul Harun ini digunakan alur padat, meskipun peristiwa fungsionalnya tidak susul-menyusul dengan cepat, tapi hubungan antara peristiwa satu dengan yang lainnya terjalin cukup erat dan tidak dapat dipisahkan atau dihilangkan salah satunya. Jika itu dilakukan, maka pembaca akan merasa kehilangan cerita dan kurang memahami hubungan sebab akibat dari cerita yang disajikan.

Pertama, pengarang mengenalkan tentang tokoh utama serta tokoh pendukungnya dan menggambarkan tentang peristiwa yang terjadi dan kemudian mengacuh pada konflik yang terjadi antar tokohnya dengan bagian akhir yang menggambarkan hasil yang didapatkan oleh tokoh-tokoh dari konflik yang terjadi dalam rangkaian cerita. Pada awal cerita pengarang menggambarkan kedatangan Rafilus ke Kurai Taji untuk memenuhi amanat ibu dan adik-adiknya untuk menjemput sang ayah agar mau berobat di Jakarta. Kedatangan Rafilus ke Kurai Taji tidak sejalan dengan rencana awal yang telah ia susun. Akibat dari sang ayah yang menolak ikut dengannya ke Jakarta dan lebih memilih tinggal di rumah keluarganya dan ayahnya juga berharap Rafilus mau menemaninya di Kuraitaji sampai ia dipanggil oleh sang pencipta. Membuat Rafilus harus terlibat dalam konflik perebutan harta warisan dari kaum sang ayah. Rafilus harus bertemu dan berhubungan dengan orang-orang licik yang menginginkan harta warisan dari ayahnya. 
Rafilus tidak hanya terlibat dalam konflik perebutan harta warisan sang ayah. Rafilus juga terlibat hubungan dengan beberapa wanita yang ada di Kuraitaji, sebut saja Maimunah, Arneti, Farida dan Upiak Dedok. Dari semua wanita itu, hanya dengan Arnetilah Rafilus memiliki hubungan yang jelas secara adat dan agama Islam. Walau pada akhir cerita Maimunahlah yang menjadi wanita pilihan dari Rafilus.

Akhir dari konflik perebutan harta warisan Bagindo Tahar hanyalah sebuah surat warisan yang berisikan surat-surat kepemilikan atas tanah, sawah, dan ladang dari Bagindo Tahar yang hampir semuanya sudah digadaikan dan tidak ada lagi harta yang menjadi hak penuh dari Bagindo Tahar. Orang-orang yang menginginkan harta warisan tersebut hanya pulang dengan tangan kosong karena tidak ada satu pun yang ingin menebusnya.

Konflik yang terlihat dalam novel ini adalah konflik antar tokohnya untuk mendapatkan harta warisan. Namun tidak semuanya peristiwa dalam novel ini membahas tentang harta warisan Bagindo tahar, ada peristiwa yang digambarkan pengarang di luar konflik utamanya, yaitu tentang harta warisan tapi masih memiliki kaitan dengan peristiwa utamanya. Misalnya, penggambaran tradisi uang jemputan yang ada dalam adat Pariaman. Uang jemputan yang didapat oleh Rafilus dari pinangan keluarga Arneti kemudian pengarang juga memaparkan hubungan terlarang hampir semua tokohnya yang secara tidak langsung menggambarkan bagaimana tingkah laku dan pola berpikir tokoh-tokohnya yang jauh dari aturan adat dan agama Islam.

\section{Aspek Tokoh dan Penokohan}

Tokoh merupakan manusia imajinatif yang diciptakan pengarang yang membentuk watak dan prilaku. Sedangkan, penokohan merupakan cara menampilkan citra tokoh dalam karya sastra (Sujdiman, 1992:58). Tokoh utama dalam novel Warisan karya Chairul Harun ini adalah Rafilus. Rafilus digambarkan oleh pengarang sebagai tokoh yang membawa awal dari konflik yang ada dalam cerita novel Warisan ini. Kedatangannya ke Kurai Taji dianggap oleh orang-orang kampung untuk mengambil bagian dari harta warisan Bagindo Tahar. Sepanjang alur dalam cerita, hampir setiap latarnya menggambarkan tentang konflik perebutan harta warisan. Kehadiran tokohtokoh pendukung menunjang jalannya cerita dalam novel Warisan ini yang erat kaitannya dengan Rafilus, hingga Rafilus dikatakan sebagai pemeran utama dari cerita novel Warisan karya Chairul Harun ini.

Di samping itu ada tokoh-tokoh lainnya seperti Bagindo Tahar, Sidi Baharudin, Siti Baniar, Maimunah, Arneti, Farida dan masih banyak lagi. Tokoh-tokoh ini dihadirkan secara analitis, artinya dalam novel dipaparkan secara langsung maupun tidak langsung mengenai watak-watak dari tokoh tersebut.

Rafilus adalah seorang pemuda tampan yang tergambar dari bentuk fisiknya yang tinggi dan memiliki wajah rupawan dan kulit yang bersih, ia juga seorang pemuda yang pandai, terbukti dengan gelar Doktorandus yang telah diraihnya serta sikap tenangnya ketika berhadapan dengan orang-orang licik yang memiliki tujuan untuk mendapatkan bagian dari harta Bagindo Tahar.

“Pak Wali tahu bahwa saya baru datang. Lebih baik hal ini dibicarakan dengan Etek Baniar. Ia pemegang pura dan kekuasaan atas harta yang ada di rumah ini."

"Ayahmu setuju. Kini tergantung padamu saja. Kalau ringgit emas memang tak ada, aku bersedia meminjam pada orang lain atas namamu atau ayahmu." Rafilus tertawa. Ia memandang kelicikan Sidi Karawai sebagai sebuah lelucon (Harun, 1979:35).

"Dapatkah Ajo membantu aku?"

"Apa?"

"Mendapatkan sebidang tanah untuk perumahan." 


\section{Jurnal Elektronik WACANA ETNIK - Vol 7 No 1 April 2018, (36 - 57) \\ p ISSN 2089-8746, e ISSN 2302-7142}

"Lebih baik langsung kau minta pada ayah. Siapa tahu ayah mau memberikan hibah untuk mu.

Syukur kalau Etek Baniar dan Ajo Bandar setuju pula."

"Rupanya Ajo tidak mau menolong ku "

“Terserah apa anggapanmu padaku "(Harun, 1976:37).

Rafilus memang memiliki sikap yang tenang dan berwibawa bila berhadapan dengan orang-orang yang menginginkan harta warisan sang ayah. Tapi bila berhadapan dengan wanita, Rafilus menjadi orang bodoh yang hanya mengikuti perasaan dan hawa nafsu semata tanpa diiringi dengan logika dan pemikiran yang logis. Ia menjadi tidak sabaran bila dihadapkan pada nafsunya mengenai wanita yang ia nilai untuk pertamanya dari seorang wanita adalah bentuk fisik dari wanita tersebut. Pola hidup dan pergaulan bebas yang ia dapat di Jakarta itulah yang ia bawakan pada Upiak Dedok, Maimunah, Farida dan Arneti yang sudah digambarkan dari beberapa ulasan di atas. Rafilus hanya mengikuti apa yang dirasakan oleh nalurinya sebagai laki-laki ketimbang bertindak dengan menggunakan akal pikirannya yang tentu tindakan ini tidak sesuai dengan adat dan agama Islam.

Sikapnya yang mengutamakan prinsip kebebasan, Rafilus tetaplah seorang anak yang menyayangi orang tuanya. Hal ini terlihat ketika Rafilus memutuskan untuk ikut tinggal di Kuraitaji bersama ayahnya hingga ayahnya mau meninggalkan Kuraiaji dan ikut dengan dirinya tinggal di Jakarta. Rafilus harus terlibat konflik dari perebutan harta warisan kaum ayahnya, walau jauh sebelum ia datang ke Kuraitaji, ibunya sudah memperingatinya untuk tidak melibatkan diri dalam konflik harta warisan Bagindo Tahar. Tetapi, atas rasa homat dan sayangnya pada Bagindo Tahar. Ia menerima permintaan Bagindo Tahar yang memintanya untuk menjadi ahli waris sang ayah ketika beliau telah meninggl nanti, ia yang bertanggung jawab atas pembagian harta warisan Bagindo Tahar. Rafilus juga mengambil ahli tanggung jawab segala urusan rumah tangga tempat tinggal di bakonya hingga pada segala keperluan dari kematian Sidi Baharudin dan Siti Baniar. Semua itu Rafilus lakukan atas rasa sayangnya pada Bagindo Tahar. Kesedihan yang cukup mendalam juga ia rasakan ketika ayahnya pergi untuk melamalamanya.

Walaupun ia dibesarkan jauh dari ayahnya dan harus berbagi kasih sayang dengan anak-anak ayahnya yang lain yang beda ibu dengannya. Kasih sayang Rafilus tetap ada untuk Bagindo Tahar, itu terlihat ketika ia menjalankan amanat dari Bagindo Tahar untuk membacakan dan membagikan harta warisan yang ditinggalkan Bagindo Tahar sebelum ia pulang ke Jakarta.

Bagindo Tahar dihadirkan pengarang sebagai alasan dari kedatangan Rafilus ke Kuraitaji yang menjadi awal memicu dari konflik dalam novel ini. Bagindo Tahar adalah seseorang yang cukup dihormati di Kuraitaji karena sifatnya yang dermawan. Ia tegas tapi baik hati hingga orang-orang di Kuraitaji cukup segan dengannya dan ia begitu dihargai oleh orang-orang yang dekat dengan dirinya, di luar dari harta yang ia miliki. Hal ini terlihat pada kutipan di bawah ini,

“ Berlainan dengan kematian Sidi Baharudin dan Siti Baniar, kematian Bagindo Tahar mendapat perhatian dari segenap lapisan masyarakat Kuraitaji. Ia tidak pernah dianggap sebagai laki-laki yang kurang ajar serta berbisa mulutnya. Ia tegas tetapi baik hati, banyak orang yang dibantunya. Ia tidak pernah meributkan sewa tanah atau sewa rumah yang tidak dibayar. Ia tidak pernah rewel menagih hutang. Kecerdasan dan kekayaannya menyebabkan ia dianggap sebagai pemimpin masyarakat. Hanya adik dan kemenakannya yang memudarkan kepemimpinannya. Kesayangannya pada adik dan kemenakannya menyebabkan ia sering tidak perduli atas keluhan orang lain yang jadi korban tingkah kurenah kedua keluarganya itu" (Harun, 1979:127). 
Bagindo Tahar juga digambarkan oleh pengarang yang mencerminkan seorang ayah yang tidak ingin merepotkan anak dan istrinya walau ia sudah tidak sekuat dahulu dan sering sakit-sakitan hingga ia memilih tinggal di rumah keluarganya. Alasan Bagindo Tahar memilih tinggal di rumah keluarganya dari rumah istri dan anaknya di Jakarta, selain tidak mau menjadi beban dalam kehidupan anak-anaknya juga karena tanggung jawabnya sebagai seorang mamak dalam keluarganya yang harus menjaga harta yang dimiliki oleh keluarganya sampai ia mati.

Bagindo Tahar mengalami kesulitan dalam dirinya, kalau ia pergi mengikuti ajakan Rafilus maka adik dan kemenakannya akan ditinggal begitu saja dalam keadaan sakit. Berarti seluruh harta benda yang ada akan punah sebelum keduanya diantar ke dalam liang lahar. Ia tidak percaya pada orang-orang yang mengaku peduli pada keluarganya, mereka hanya peduli pada harta keluarganya saja. Inilah alasannya ia memilih menghabiskan sisa hidupnya untuk melaksanakan tugasnya sebagai seorang kakak dan mamak dalam keluarganya. Kalau mereka bertiga sudah meninggal maka terserah mau diapakan hartanya tersebut tapi sebelum itu terjadi ia ingin menjaganya sebagai bentuk tanggung jawabnya.

Siti Baniar adalah adik dari Bagindo Tahar yang berarti Bako bagi Rafilus. Siti Baniar dihadirkan oleh pengarang sebagai seseorang wanita yang sudah mengalami sakit hampir 10 tahun dan tidak memiliki anak perempuan yang membuat garis keturunan keluarganya terancam punah karena Minangkabau menganut sistem Matrilineal dimana garis keturunan menurut garis ibu . Ia hanya memiliki seorang anak laki-laki dan itupun keadaannya hampir sama dengan dirinya yang sudah terbaring di tempat tidur hampir 10 tahun lamanya. Siti Baniar tidak terlalu suka pada Rafilus, karena menurutnya kedatangan Rafilus ke Kuraitaji hanya untuk mengambil bagian dari harta warisan ayahnya. Siti Baniar menganggap kedatangan Rafilus bukanlah rasa peduli anak pisang terhadap bakonya yang sedang sakit. Ketidaksukaan Siti Baniar terhadap Rafilus tergambar pada kutipan di bawah ini.

Sidi Baharudin dihadirkan oleh pengarang sebagai anak dari Siti Baniar dan kemenakan dari Bagindo Tahar yang berarti memiliki hubungan sepupu dengan Rafilus yang berasal dari keluarga ayahnya. Sidi Baharudin digambarkan sebagai seseorang yang memiliki sifat sombong karena kekayaan yang dimiliki keluarganya hingga apapun dapat dibeli dengan uang. Ditambah ia merupakan satu-satunya anak dari Siti Baniar. Selain sombong, Sidi Baharudin juga suka berucap sesuka hatinya dia tidak akan memikirkan apakah ucapannya itu menyakiti hati lawan bicaranya atau tidak. Sidi Baharudin juga tidak senang dengan kehadiran Rafilus di rumahnya, karena itu akan mengancam posisinya sebagai satu-satunya yang berhak akan harta keluarganya. Hingga ia langsung berkata kasar pada saat pertama bertemu Rafilus.

Maimunah adalah kemenakan jauh dari Bagindo Tahar yang ikut membantu mengurus Bagindo Tahar saat beliau sudah mulai sakit-sakitan. Maimunah dihadirkan oleh pengarang yang memiliki hubungan sangat erat kaitannya dengan tokoh utama karena dengan Maimunahlah nantinya hubungan cinta Rafilus berakhir. Maimunah hanya seorang wanita yang kesepian dan haus akan kasih sayang dari seorang suami. Ia memilih bercerai dari suaminya karena suaminya hanya perduli pada pandangan orang akan kekayaan yang dimiliki oleh suaminya hingga ia merasa bisa menjadi suami terhormat di mata Maimunah tapi malah mengabaikan dirinya yang juga ingin dimanja dan diperhatikan layaknya perlakuan seorang suami pada istrinya.

Tokoh Arneti dihadirkan oleh pengarang sebagai teman kecil dari Rafilus yang berujung menjadi istri dari Rafilus. Namun pernikahan mereka hanya sebatas status belaka tidak hak dan kewajiban yang mereka 
laksanakan dalam hubungan sebuah pernikahan, baik secara adat maupun agama islam. Terpengaruh akan pergaulan bebas di kota besar membuat pola berpikir Arneti ikut berubah dalam memandang arti sebuah kebebasan itu tidak ada batasnya. Ia lupa akan adat istiadat dan agama islam yang mengikatnya. Hingga ia kehilangan keperawanannya dengan laki-laki yang bukan suaminya.

Sikap Arneti tidak menggambarkan bagaimana sikap dan prilaku gadis Minangkabau yang harus menjaga harkat dan martabat dirinya di depan laki-laki. Arneti memang miliki wajah yang cantik, lahir dan dibesarkan dari keluarga yang cukup kaya, ditambah lagi ia akan menamatkan pendidikannya di salah satu universitas swasta di Padang, hingga nantinya akan bergelar sarjana. Hal itu membuatnya bersikap layaknya gadis-gadis perkotaan. Hal ini terlihat pada kutipan di bawah ini.

“Arneti puas pada dirinya. Sikap Rafilus tidak berubah masih seperti masa kanak-kanak. Lama juga Rafilus terbaring di atas pondok itu, ia terbangun oleh bibir Arneti yang mencecah pada bibirnya" (Harun, 1979:30).

Arneti juga tidak memperlihatkan bagaimana sikap seseorang perempuan yang semestinya pada calon keluarga suaminya saat keluarga itu mengalami musibah dengan kematian Siti Baniar. Hal ini terlihat pada kutipan di bawah ini.

"Rafilus muak melihat Arneti yang datang sebagai orang asing dengan pakaian pesta dan tidak mau masuk ke dalam kamar ayahnya. Gadis itu tidak pula meringankan tangan membantu pekerjaan penyelenggaraan penguburan.

“Nanti pakaian Ar kotor " katanya sambil mengerutkan kening, kemudian ia mondar mandir mempertontonkan dandanann sambil memberikan senyuman pada orang yang ditemuinya dalam rumah itu" (Harun, 1979:109-110).

Dalam pikiran Arneti, ia hanya membutuhkan Rafilus yang bisa menyelamatkan harga dirinya di mata masyarakat Kuraitaji. Selain dari Rafilus Arneti tidak perduli termasuk keluarga bahkan ayah Rafilus sendiri. Arneti hanya peduli pada kebanggaannya karena keluarganya bisa meminang Rafilus yang memiliki status yang cukup tinggi di Kuraitaji.

Dari uraian tentang watak tokoh di atas, hanya tokoh-tokoh yang terlibat langsung dengan tokoh utama. Selain itu masih ada tokoh-tokoh tambahan yang lain yang tidak dianalisis secara detail, karena dalam novel ini tokoh-tokoh tersebut tidak banyak berkaitan dengan tokoh utama. Tokoh-tokoh tersebut hanya sebagai tokoh pendukung di dalam novel. Namun tokoh-tokoh tersebut secara garis besarnya sudah tergambarkan dari beberapa ualasan di atas seperti, Asnah istri dari Sidi Baharudin yang lebih memilih melayani Tan Rudin dari pada suaminya sendiri, " la lebih banyak melayani dukun dari pada lakinya."

\section{STRUKTUR KEMAKNAAN}

Struktur kemaknaan berfungsi untuk melibatkan tata hubungan antara struktur cerita dan struktur penceritaan yang membentuk suatu totalitas kemaknaan sebagai tema mayor, yang identifikasi sebagai pandangan dunia kolektif masyarakat yang dituangkan pengarang ke dalam sebuah karya sastra (Hasanuddin, 1991).

Novel Warisan karya Chairul Harun ini merupakan refleksi dari pandangan dunia pengarang yang terefleksikan melalui tokoh utama dalam novel ini. Pandangan dunia pengarang dalam novel Warisan berisikan protes terhadap perubahan yang terjadi dalam masyarakat Minangkabau dalam bentuk prilaku dan sikap yang tidak sejalan lagi dengan falsafah Minangkabau akibat dari perubahan tatanan sosial masyarakat pada zamannya 
dari pengaruh kolonial dan persentuhan dengan budaya lain (modernisasi), sedangkan tema mayor novel Warisan adalah perubahan moral masyarakat Minangkabau. Hidup dalam kemunafikan, diluarnya tampak begitu memegang teguh apa yang menjadi landasan mereka, namun jauh di dalamnya mengalir arus kebebasan yang menganggap aturan-aturan itu hanya tulisan pada sebuah kertas, tidak ada efeknya bagi mereka. Mereka hanya mementingkan kenikmatan hidup duniawi semata. Hal ini didukung oleh beberapa bentuk sikap dan perilaku tokoh dalam novel ini sebagai berikut :

1. Perlakukan Rafilus pada Maimunah, Farida dan Upiak Dedok dengan memakai prinsip kebebasan dan atas dasar suka sama suka serta tidak ada yang dirugikan maka apa yang mereka lakukan mereka anggap tidak itu biasa saja untuk memenuhi hasrat mereka akan kenikmatan duniawi.

2. Tuanku Salim, Asnah, Rafilus dan Arneti yang memandang bahwa perkawinan bukanlah hal yang mengikat mereka dalam melampiaskan kesenangan mereka masing-masing. Memiliki hubungan terlarang dengan pasangan yang bukan pasangan mereka bukanlah hal yang perlu mereka takuti dan mereka tutupi.

3. Harkat dan martabat tokoh perempuan-perempuan dalam novel ini seakan-akan tidak mencerminkan perempuan Minangkabau yang sesungguhnya. Perempuan Minangkabau yang nantinya akan disebut sebagai bundo kandung (perempuan yang dihormati dan menjadi panutan) bagi masyarakat Minangkabau.

\section{Fakta Kemanusian}

Fakta kemanusian adalah segala hasil aktivitas atau perilaku manusia yang berwujud aktivitas sosial tertentu, aktivitas politik tertentu, maupun kreasi kultur seperti filsafat, seni rupa, seni music, seni patung, dan seni sastra. Goldman menganggap bahwa semua fakta kemanusian merupakan struktur yang mempunyai arti tertentu. Fakta kemanusian dikatakan mempunyai arti karena merupakan hasil usaha manusia mencapai keimbangan yang lebih baik dalam hubungannya dengan dunia sekitarnya (Faruk, 2003).

Novel Warisan karya Chairul Harun yang diterbitkan pada tahun 1979 adalah sebuah karya yang berlatarkan sosial budaya Minangkabau yang lahir sesudah penjajahan kolonial dan mulai bersentuhannya budaya lokal dengan budaya luar akibat modernisasi. Hal ini turut mempengaruhi pola pikir dan susunan sosial masyarakat Minangkabau yang tradisional ke arah yang baru hingga mengalami perubahan secara perlahan. Mengakibatkan timbulnya gejala-gejala sosial dalam masyarakat Minangkabau dari perubahan itu yang menjadi fakta-fakta kemanusian yang ada dalam novel Warisan.

Chairul Harun ingin gambaran bahwa permasalahan tentang harta pusaka di Minangkabau masih menimbulkan pro dan kontra di kalangan masyarakatnya. Terutama pada pembagian harta warisan yang selalu berakhir sengketa yang bisa memecah belah keluarga. Manusia akan menjadi sangat serakah apabila berhubungan dengan harta, tahta dan kekuasaan. Gambaran seperti itu yang ada dalam novel Warisan, sikap yang penuh dengan rasa saling curiga dan itu terlihat ketika kedatangan Rafilus ke Kurai Taji yang disalahartikan oleh keluarga ayahnya. Keluarga ayahnya mengira ia datang untuk merebut harta warisan yang akan ditinggalkan oleh Bagindo Tahar. Setidaknya itulah yang dipikirkan oleh Siti Baniar, Sidi Baharudin dan beberapa orang kampung yang ada mengenal keluarga Bagindo Tahar. Setelah kedatangan Rafilus di keluarga ayahnya, keesokannya mulai berdatangan satu persatu orang yang mengaku sebagai kerabat dekat maupun kerabat jauh dari Bagindo Tahar yang juga menginginkan harta warisan tersebut. 
Dalam novel Warisan, fakta kemanusiaan yang coba diungkapkan oleh Chairul Harun adalah mengenai nilai sebuah perkawinan yang ada di Minangkabau. Menurut Amir (Amir, 2006), fungsi perkawinan adalah sebagai sarana legalisasi hubungan seksual antara wanita dengan laki-laki yang dipandang dari adat, agama dan undang-undang Negara, penentuan hak dan kewajiban suatu perlindungan atas suami, istri dan anak-anak dan memelihara kelangsungan hidup kekerabatan dan menghindari kepunahan. Perkawinan adalah sesuatu hal yang sangat sakral dan memiliki fungsi mengikat bagi suami dan istri atas hak dan kewajiban yang harus mereka lakukan dalam menjalani sebuah perkawinan. Namun, itu tidak tampak dalam novel Warisan. Chairul Harun menggambarkan bahwa pernikahan yang dijalani oleh masyarakat Minangkabau sangat rapuh. Rapuhnya fondasi sebagai dasar untuk membangun sebuah perkawinan. Perkawinan yang digambarkan dalam novel Warisan adalah perkawinan yang hanya berfungsi untuk mencapai tujuan masing-masing, tanpa mengikutsertakan hak dan kewajiban yang sesungguhnya dari sebuah perkawinan.

Perkawinan bagi Rafilus dan Arneti adalah sebuah Toleransi, Rafilus menerima pinangan dari keluarga Arneti hanya untuk menolong menyelamatkan harga diri Arneti di mata keluarga dan masyarakat Kurai Taji yang sudah tidak perawan lagi. Hak dan kewajiban tidak tambak dalam perkawinan keduanya. Rafilus yang memerikan malam pertama perkawinannya pada Farida yang tidak memiliki status yang sah dengannya dan lebih memilih tinggal dalam kelaurga ayahnya dari pada tinggal di rumah Arneti. Kemudian Arneti yang sudah memiliki pacar lagi meskipun statusnya masih istri sah dari Rafilus. Perwakinan antara Asnah dan Sidi Baharudin serta perkawinan Siti Baniar dan Tuanku Salim juga hampir sama dengan pernikahan Rafilus dengan Arneti. Pernikahan mereka hanya berlandasan pada kepentingan materi. Asnah dan Tuanku Salim hanya memanfaatkan kekayaan yang dimiliki oleh Siti Baniar dan Sidi Baharudin, sedangkan di belakang keduanya Asnah dan Tuanku salim bebas bermain gila dengan pasangan yang bukan muhrim mereka.

Dalam novel Warisan, Chairul Harun tidak hanya menggambarkan bagaimana rapuhnya sebuah fondasi pernikahan masyarakat Minangkabau, tetapi juga mengungkapkan bahwa hubungan antara induak bako dengan anak pisang kurang harmonis. Hal ini dikarenakan Minangkabau yang menganut sistem Matrilineal, anak yang lahir dalam perkawinan yang ada di Minangkabau akan tinggal dan besar dilingkungan keluarga ibunya. Anakanak yang lahir dari perkawinan ini membentuk hubungan antara anak-anak dengan pihak keluarga ayahnya yang disebut hubungan anak pisang dengan induak bako kurang akrab dan kurang hangat. Hanya sebatas hubungan formal dan jika diperlukan terutama dalam hal-hal penting yang berhubungan dengan keluarga, seperti perkawinan, kelahiran, dan kematian (Amir, 2006). Hal itu terlihat dari hubungan anak pisang dan induak bako antara Rafilus dengan Siti Baniar yang kurang harmonis dan lebih terlihat seperti hubungan yang asing yang menimbulkan rasa benci dan saling curiga antara keduanya.

Dalam novel Warisan ini, Chairul Harun juga mengungkapkan fakta kemanusian mengenai hubungan antara laki-laki dan perempuan yang tidak dengan sesuai dengan nilai-nilai dan norma yang ada dalam masyarakat Minangkabau serta agama Islam. Hubungan antara laki-laki dan perempuan yang ada dalam novel ini tidak sesuai dengan hubungan antara laki-laki dengan perempuan yang diatur oleh adat istiadat Minangkabau dan agama Islam sebagai agama orang Minangkabau. Hubungan singkat yang diperlihatkan oleh Rafilus terhadap Upiak Dedok hanya karena rasa dongkol dan benci terhadap Upiak Dedok yang bekerja sama dengan Tuangku Salim dalam memanfaatkan harta ayahnya. Hal itu terlihat pada kutipan di bawah ini. 
“ Meskipun Upiak Dedok tidak secantik Asnah atau Arneti, tetapi karena kejengkelan Rafilus, perempuan ini tetap merangsang birahinya. Dekat rumpun bambu ia memegang bahu perempuan itu dan mendekapnya erat-erat. Rasa dongkol Rafilus lenyap untuk sementara ketika ledakan birahinya di siang itu melelahkannya.

“ Lain kali aku mengunjungi ibumu," kata Rafilus pada Upiak Dedok yang sedang memasang meneliti bajunya" (Harun, 1979:39).

Tinggal di lingkungan dengan segala arus kebebasan yang ada di kota besar seperti Jakarta membuat Rafilus bertindak hanya mengikuti keinginan hatinya. Walaupun apa yang dia lakukan tidak sesuai dengan norma dan syariat Islam. Sejak awal kedatangan Rafilus ke Kurai Taji. Maimunah memang sudah menaruh perhatian terhadap Rafilus, begitu pun sebaliknya. Jadi Maimunah tidak akan menolak perlakuan Rafilus terhadapnya dan ia memang sudah berjanji akan mengabdikan diri pada Rafilus meskipun Rafilus waktu itu sudah terikat oleh tali pertunangan dengan Arneti. Tindakan seperti itu juga terlihat ketika ia lari dengan Farida pada malam pertama pernikahannya dengan Arneti, malam setelah ia melaksanakan pesta pernikahannya dengan Arneti. Malam pengantin yang harusnya ia lakukan bersama istrinya, Arneti malah ia lakukan dengan Farida.

Hubungan antara Asnah dan Tan Rudin, hubungan gelap yang mereka bangun di belakang Sidi Baharudin yang merupakan suami sah dari Asnah. Hubungan yang dijalani oleh Asnah dan Tan Rudin tampa rasa takut sama sekali mereka sadar dengan hubungan terlarang itu tapi mereka tetap melakukannya demi kenikmatan dunia semata.

“ Tan Rudin tersenyum, melempar sehelai bulu ayam ke lekuk buah dada Asnah. Asnah menekur. Bulu ayam di lekuk buah dadanya dibiarkan saja.

"Anak Bagindo Tahar yang baru datang itu rupanya mau menghabiskan harta ayahnya."

"Mungkin."

"Aku lihat kau senang padanya."

Asnah mencubit Tan Rudin. Dukun itu membalas dengan meremas dada Asnah. Keduanya sama-sama tertawa.

Rafilus memperhatikan semuanya kejadian itu dari belakang rumpun pisang. Ia menjauh ketika Tan Rudin dan Asnah berpeluk-pelukan” (Harun, 1976:40).

Secara tidak langsung hubungan yang seperti di atas menggambarkan bahwa wanita Minangkabau seakan-akan tidak memiliki harga diri dan martabat sebagai seorang wanita. Rela hanya menjadi pelampiasan hawa nafsu dari laki-laki yang tidak memiliki ikatan yang sah dengan mereka hanya demi sebuah kenikmatan duniawi semata dan materi yang kapan saja bisa hilang tak berbekas.

Tidak semua fakta kemanusian yang digambarkan dalam novel Warisan ini yang bersifat menyimpang. Ada fakta kemanusian lainya yang ditunjukkan oleh Bagindo Tahar ketika ia menolak ajakan Rafilus untuk berobat di Jakarta. Bagindo Tahar tidak ingin menjadi beban bagi anak dan istrinya. Hal ini terlihat dalam kutipan di bawah ini.

“ Aku tidak ingin jadi beban kalian. Seorang ayah tidak patut jadi beban bagi anak-anaknya. Hal ini juga telah aku jelaskan pada ibumu. Dan sejak dulu aku pun tidak ingin anak-anakku jadi beban dalam kaumku. Aku telah mewariskan darah, tubuh dan perangai pada anak-anakku. Warisan ini tidak dapat digugat siapapun. Pada pengadilan mana pun ( Harun, 1979:19).

Meskipun sudah dalam keadaan yang tidak sehat lagi, namun Bagindo Tahar masih tetap mempertanggungjawabkan kewajibannya untuk menjaga adik dan kemenakannya serta harta yang dimiliki 
keluarganya. Bagindo Tahar tidak mau menyelamatkan dirinya sendiri, ketika ia tidak mau mengiyakan ajakan Rafilus untuk berobat di Jakarta. Hal itu terlihat pada kutipan di bawah ini.

“ Ia tidak percaya bahwa adik dan kemenakannya itu akan diperhatikan sanak keluarga yang jauh. Keluarga menurut sistem matrilineal sudah tak ada lagi. Mereka bertiga merupakan generasi terakhir dari sebuah kaum yang berkuasa dan terhormat. Kini mereka terancam kepunahan karena Siti Baniar tidak pernah melahirkan anak perempuan (Harun, 1979:21).

Keinginan Rafilus untuk tetap menikahi Maimunah, meskipun sebelum Rafilus pulang ke Jakarta, Maimunah telah menolak lamarannya tapi tiga bulan kemudian ia datang kembali ke Kurai Taji untuk berziarah ke makam ayahnya juga untuk meminta kembali Maimunah menjadi istrinya. Hal ini menunjukkan bahwa Rafilus ingin tetap mempertahankan sistem matrilineal keluarganya, kalau ia menikahi perempuan di luar perempuan Minangkabau maka sistem matrilinealnya akan hilang.

\section{Subjek Kolektif}

Subjek kolektif merupakan subjek yang mengatasi individu yang di dalamnya individu hanya merupakan bagian. Subjek kolektif bukan kumpulan individu yang berdiri sendiri, melainkan suatu kesatuan kolektivitas. Subjek kolektif bisa juga dikatakan sebagai subjek fakta sosial dari satu pandangan dunia, hanya kelompok sosial yang menjadi gagasan dan aktivitasnya cenderung ke arah penciptaan suatu pandangan dunia. Subjek kolektif itu dapat berupa kelompok kekerabatan, kelompok sekerja, kelompok teritorial dan sebagainya (Faruk, 2003).

Chairul Harun yang dilahirkan dan hidup dalam lingkungan adat dan budaya Minangkabau dan ia merupakan bagian dari masyarakat sosial Minangkabau. Sebagai bagian dari masyarakat, ia dapat melihat dan menangkap fakta-fakta sosial yang berkembang dalam masyarakat Minangkabau dan mengungkapkannya melalui karya sastra. Pandangan dunia pengarang bukan hanya melihat pada ideologi tersendiri yang dimiliki oleh pengarang. Melainkan ideologi yang terdapat ada suatu kelompok kolektif tertentu yang terwakilkan oleh pengarang sebagai bagian dari kelompok sosial tersebut.

Fakta kemanusiaan yang dihadirkan dalam novel Warisan merupakan hasil dari aktivitas dan perilaku manusia sebagai bagian dari kelompok sosial atau subjek kolektif tertentu. Selain dari bagian kelompok kolektif Minangkabau, Chairul Harun merupakan bagian dari kelompok intelektual Minangkabau. kelompok Intelektual itu terdiri dari budayawan, sejarawan dan kalangan akademik.

Sebagai salah satu dari kelompok intelektual Minangkabau, Chairul Harun pernah diundang ke beberapa Negara, seperti AS, Jepang, India, Malaysia untuk bertukar pengetahuan tentang Knowledge and Minangkabau Culture. Ia diundang untuk memaparkan bagaimana dan apa itu budaya Minangkabau. pengetahuan Chairul Harun tentang budaya Minangkabau ia dapat dari pendidikan non formalnya dan kepekaan akan budaya dan tradisi Minangkabau.

Chairul Harun pernah menjadi wartawan Majalah Dewi di Jakarta dan Harian Aman Makmuchair di Pekanbaru. Kemudian menjadi Kontributor Mingguan Singgalang yang mengukuhkan kembali identitas orang Minangkabau akibat trauma PRRI (Pemerintahan Revolusioner Republik Indonesia), Chairul Harun diserahkan sebuah rubrik Iduk Baraka, Mati Bariman. Dengan rubrik ini, Chairul Harun mulai bebas mengutarakan dan menuangkan pikiran dan ide-idenya tentang keminangkabauan. Tidak hanya itu Chairul Harun juga bisa 
menyampaikan kritikan dan apresiasinya pada budaya dan pemerintahan bangsa ini melalui karya-karya sastra yang dia lahirkan.

Penelitian di atas merefleksikan pandangan dunia dari subjek kolektif yang terefleksi dalam novel ini meliputi kelompok intelektual Minangkabau yang memperoleh pendidikan tinggi dan juga hidup di perantauan, kosmopolit, serta berinteraksi dengan orang-orang yang berada di luar Minangkabau. Hal itu dihadirkan pengarang untuk menjawab fakta-fakta kemanusian yang terdapat pada saat kelahiran novel Warisan ini.

Identifikasi terhadap subjek kolektif pandangan dunia di atas sejalan dengan pandangan dunia Taufik Abdullah pada kata pengantar dalam buku karangan A.A Navis, Alam Takambang Jadi Guru yang mengatakan bahwa kaum intelektual Minangkabau banyak memberikan kritikan terhadap adat yang mendorong untuk terjadinya perubahan sekaligus memberikan kontrol bagi sejauh mana perubahan itu mesti dilakukan (Navis, 1984).

Banyak tokoh-tokoh intelektual Minangkabau yang mengkritik adat Minangkabau yang telah mengalami perubahan dalam bentuk perilaku dan sikap masyarakatnya. Apa yang dilakukan oleh masyarakat Minangkabau sudah tidak sejalan lagi dan melenceng dari falsafah Minangkabau yang selama ini begitu dijunjung tinggi oleh masyarakatnya akibat dari modernisasi dan pengaruh pemerintahan Kolonial Belanda. Tokoh-tokoh intelektual Minangkabau itu seperti Wisran Hadi dalam karyanya yang fenomenal, yaitu novel Siti Nurbaya.

\section{Pandangan Dunia}

Goldmann mengatakan bahwa pandangan dunia adalah istilah yang cocok untuk kompleks yang menyeluruh dari gagasan-gagasan, inspirasi dan perasaan, yang menghubungkan secara bersama-sama anggota suatu kelompok sosial tertentu dan mempertentangkannya dengan kelompok-kelompok sosial yang lain sebagai suatu pemahaman kesadaran subjek kolektif. Seseorang individu, dalam hal ini adalah pengarang tidak mungkin memiliki pandangan dunianya (world view) sendiri. Ia akan menyuarakan pandangan dunia suatu kelompok sosial tertentu (transindividual subject), di mana pengarang merupakan bagian dari kelompok masyarakat (Faruk, 1988, 2003)

Pandangan dunia menghubungkan antara karya sastra dengan kehidupan masyarakatnya. Hal ini disebabkan oleh kenyataan bahwa pandangan dunia dipandang sebagai produk dari hubungan antara kelompok sosial yang memilikinya dengan situasi sosial dan ekonomi pada saat tertentu. Goldmann menyatakan bahwa pandangan dunia merupakan struktur metal pengarang yang dituangkan dalam karya sastra (Faruk, 2003). Pandangan dunia adalah segenap gagasan, perasaan dan aspirasi yang kompleks yang menghubungkan dan mempertentangkan kelompok sosial tertentu dengan kelompok sosial tertentu lainnya sebagai suatu pemahaman kesadaran subjek kolektif. Goldmann menjelaskan bahwa untuk mengetahui pandangan dunia pengarang, harus dilihat dari segi struktur cerita. Dari struktur cerita inilah yang kemudian dicari jaringan-jaringan yang membentuk kesatuan. Untuk mencapai pemahaman terhadap pandangan dunia pengarang, struktur cerita tersebut harus dipahami melalui pembacaan teks di mana teks tersebut melatarbelakangi penciptaan suatu karya sastra (Fananie, 2000).

Pandangan dunia seorang Chairul Harun yang terefleksi dalam novel Warisan menganggap bahwa saat ini, pola pikir, tingkah laku dan sikap yang ditunjukkan oleh masyarakat Minangkabau sudah tidak sejalan dengan falsafah adat Minangkabau yang berlandaskan pada Adat Basandi Syarak. Syarak Basandi Kitabullah. Pernyataan 
yang mengatakan bahwa Minangkabau adalah suku bangsa yang beradat dan menjunjung tinggi nilai-nilai yang ditinggalkan oleh para leluhur berupa pola pikir yang cerdas, etika moral yang baik dan budi pekerti yang mulia di mana semuanya berlandaskan pada aturan adat dan agama Islam. Pernyataan itu hanya tinggal pernyataan tanpa didukung oleh sikap yang ditunjukkan oleh masyarakatnya sendiri. pelanggaran-pelanggaran terhadap nilai-nilai yang menjadi prinsip dasar adat Minangkabau dan agama Islam, menjadi hal yang biasa dan wajar untuk mengikuti perkembangan zaman dan pengaruh budaya lain yang secara tidak langsung turut adil dalam perubahanperubahan yang terjadi di Minangkabau.

Minangkabau telah berubah, tidak seperti Minangkabau yang dahulu di mana masyarakatnya menjunjung tinggi nilai-nilai adat dan budaya yang mereka miliki. Minangkabau dengan masyarakatnya yang memiliki budi pekerti yang baik dengan kearifan lokalnya, seperti yang diungkapkan Chairul Harun dalam novel Warisan ini “ Pada masa ini tidak ada lagi yang tepat, aturan dan jadwal hanya tertulis di atas kertas”.

Minangkabau saat ini adalah Minangkabau dengan segala kemunafikan. Kemunafikan yang tergambar melalui sikap masyarakatnya, secara kolektif mereka seakan masih menjunjung tinggi nilai-nilai dan etika moral yang ada di tengah-tengah masyarakat, namun secara sikap individual mereka sudah jauh melenceng dari nilainilai tersebut. Sikap saling mencurigai dan saling memanfaatkan satu sama lainnya untuk mencapai kepentingan sendiri-sendiri. Memperebutkan sesuatu yang hanya bersifat sementara dan untuk memuaskan nafsu duniawi semata dengan mengorbankan jati diri sebagai suku bangsa yang beradat. Itulah sikap-sikap yang ditunjukkan oleh tokoh-tokoh seperti Rafilus, Arneti, Maimunah, Tuanku Salim, Asnah, Ungku Gadang, Ajo Pekok dan Upiak Denok. Melalui novel Warisan, Chairul Harun ingin memberikan gambaran bahwa tujuan hidup bukan hanya berputar untuk memiliki harta, tahta dan kekuasaan saja yang sifatnya hanya sementara dan akan hilang sewaktuwaktu tanpa disadari. Ada tujuan yang lebih bermanfaat yang sifatnya kekal. Sikap dan budi pekerti yang harusnya dimiliki oleh setiap manusia dan itu harusnya terus dibubuk dan bukannya menghilangkan secara perlahan untuk mengikuti perkembangan zaman yang menuntut sebuah perubahan dengan budaya barat sebagai kiblatnya. Namun harus disadari bahwa budaya barat tidak akan pernah cocok dengan budaya kita, yaitu budaya adat ketimuran. Ditambah lagi bahwa orang Minang mengklaim agama Islam adalah agama yang mereka anut. Dalam agama Islam apa yang dilakukan tokoh-tokoh dalam novel Warisan adalah suatu yang salah.

"Dalam surat wasiat aku tuliskan bahwa kau memang tidak berhak menerima apa pun dari harta ku. Kau hanya mengatur pembagiaan seluruh harta ku pada siapa saja yang merasa berhak menerima, karena menganggap dirinya adalah anggota kaumku atau anak-anakku. Semua mereka beranggapan yang dinamakan warisan adalah harta benda, sedangkan aku berpendapat warisan aku adalah darah perangai serta semangatku. Seluruh anak-anakku telah menerimanya. Tetapi masih ada anak-anakku yang beranggapan belum menerima warisanku. Tentu mereka mengharapkan harta. Kau berikan pada mereka" (Harun, 1979:122).

Novel Warisan memang bercerita mengenai sengketa dan konflik untuk memperebutkan harta warisan. Namun lebih dari itu Chairul Harun ingin memberikan gambaran bahwa warisan bukan hanya berupa harta benda, tapi ada warisan yang lebih bernilai dari pada itu, yaitu ajaran dan budi yang ditinggalkan. Harta benda akan habis nilai gunanya seiring waktu yang akan berjalan begitu cepat. Sedangkan budi pekerti dan kebaikan sikap dan perilaku seseorang akan selalu diingat dan diamalkan sepanjang waktu walau orangnya telah tiada. 


\section{Jurnal Elektronik WACANA ETNIK - Vol 7 No 1 April 2018, (36 - 57) \\ p ISSN 2089-8746, e ISSN 2302-7142}

\section{PENUTUP}

Berdasarkan analisis terhadap permasalahan yang terdapat dalam novel Warisan dengan menggunakan pendekatan strukturalisme genetik, terdapat beberapa unsur, yaitu unsur cerita merupakan sebuah konsep untuk menjelaskan hubungan antara unsur-unsur yang terdapat dalam sub-sub bab novel Warisan, yaitu ancaman kepunahan keluarga Bagindo Tahar, konflik perebutan harta Bagindo Tahar dan pembagian harta Bagindo Tahar. Struktur penceritaan adalah aspek-aspek teknis yang mendukung teori dalam struktur cerita, seperti aspek alur, latar serta tokoh dan penokohan. Hubungan antara struktur cerita dengan struktur penceritaan akan membentuk struktur kemaknaan, struktur yang mengukuhkan tema utama dalam novel Warisan ini, yaitu perubahan yang dialami oleh masyatakat Minangkabau dalam bentuk sikap dan perilaku yang tidak sejalan lagi dengan falsafah Minangkabau, yaitu Adat Basandi Syarak, Syarak Basandi Kitabullah. Akibat gagasan kemajuan dari persentuhan budaya Minangkabau dengan Budaya lain (modernisasi) dalam sistem ekonomi uang, pendidikan dan birokrasi.

Struktur karya mengaplikasikan struktur sosial Minangkabau yang berkaitan dengan sistem kekerabatan, perkawinan di Minangkabau salah satunya kawin bajapuik yang ada di adat Pariaman, harta pusaka dan pola dan perilaku masyarakat Minangkabau. Seorang individu bergaul dan bersikap di hadapan individu lainya serta di tengah-tengah masyarakat, baik dalam perilaku sehari-hari. Serta latar belakang yang melahirkan karya sastra yang dapat dilihat dari perjalanan hidup pengarang, yaitu Chairul Harun dan latar sosial yang berkembang dalam budaya Minangkabau ketika novel Warisan diciptakan. Sehingga mengukuhkan sebuah pandangan dunia yang terefleksi dari konflik-konflik yang ada di dalam novel Warisan. Masyarakat Minangkabau telah mengalami perubahan dalam bentuk perilaku yang mengarah pada krisis moral akibat perubahan-perubahan yang ditimbulkan dari pengaruh pemerintahan Belanda selama ada di Indonesia khususnya Minangkabau, serta persentuhan budaya Minangkabau dengan kebudayaan lain (modernisasi)telah mengubah tatanan sosial tradisional masyarakat Minangkabau. Novel Warisan memang bercerita mengenai sengketa dan konflik untuk memperebutkan harta warisan, namun lebih dari itu Chairul Harun ingin memberikan gambaran bahwa warisan bukan hanya berupa harta benda, tapi ada warisan yang lebih bernilai dari pada itu, yaitu ajaran dan budi yang ditinggalkan. Harta benda akan habis nilai gunanya seiring waktu yang akan berjalan dengan cepat. Sedangkan budi pekerti dan kebaikan sikap dan perilaku seseorang akan selalu diingat dan diamalkan sepanjang waktu walau orangnya telah tiada.

\section{DAFTAR PUSTAKA}

Amir, M. S. (2006). Adat Minangkabau Pola dan Tujuan Hidup Orang Minang. Jakarta: PT. Mutiara Sumber Widya.

Darussalam, Z. (2017). KAJIAN MIMESIS REFLEKSI DAN REFRAKSI REALITAS IMAJINATIF DAN REALITAS OBJEKTIF NOVEL WARISAN CHAIRUL HARUN. Jurnal KATA, 1(1), 72. https://doi.org/10.22216/jk.v1i1.1214

Djamari. (2010). MASALAH KEMASYARAKATAN DAN PANDANGAN CHAIRUL HARUN DALAM NOVEL WARISAN. Pujangga, l(4). Retrieved from http://garuda.ristekdikti.go.id/documents/detail/340869

Fananie, Z. (2000). Telaah Sastra. Surakarta: Muhammadiyah University Press.

Faruk. (1988). Strukturalisme Genetik dan Epistemologi Sastra. Yogyakarta: Lukman Offset.

Faruk. (2003). Pengantar Sosiologi Sastra dari Strukturalisme Genetik sampai Post Modrenisme. Yogyakarta: Pustaka Jaya.

Harun, C. (1979). Warisan. Jakarta: PT. Pustaka Jaya. 
Hasanuddin. (1991). Integrasi Adat dan Syarak Suatu Dilema Tinjauan Strukturalisme Genetik: Drama Wisran Hadi Tuanku Nan Renceh. Universitas Andalas.

Junus, U. (1986). Sosiologi Sastra: Persoalan Teori dan Metode. Kuala Lumpur: Dewan Bahasa dan Pustaka.

Navis, A. A. (1984). Alam Terkembang Jadi Guru. Jakarta: Grafitti Press.

Nurgiyantoro, B. (2002). Teori Pengkajian Fiksi. Yogyakarta: Gajah Mada University Press.

Rikardo, R. (2014). ANALISIS MASALAH SOSIAL MASYARAKAT MINANGKABAU DALAM NOVEL WARISAN KARYA CHAIRUL HARUN. SEKOLAH TINGGI KEGURUAN DAN ILMU PENDIDIKAN (STKIP) PGRI SUMATERA BARAT PADANG.

Saputri, A., Thahar, H. E., \& Hayati, Y. (2016). KONFLIK SOSIAL PADA NOVEL WARISAN KARYA CHAIRUL HARUN. Pendidikan Bahasa Indonesia, 5(2), 52-58. https://doi.org/10.24036/9836-019883

Sudjiman, P. (1991). Memahami Cerita Rekaan. Jakarta: Pustaka Jaya. 